\title{
The IDEA Method for Assessing Irrigated Cereal Farms Sustainability in Algerian Arid Zones: Case of Ouargla Region (Oued M'ya)
}

\author{
Saida Chaouch ${ }^{1}$, Zineb Djelfaoui ${ }^{1}$, Saida Kebaili ${ }^{1} \&$ Samuel Sandoval-Solis ${ }^{2}$ \\ ${ }^{1}$ University of Kasdi Merbah, Ouargla, Laboratory Phoenix, palm date's cultivation research, Faculty of Nature \\ and Life Sciences, Ouargla, Algeria \\ ${ }^{2}$ University of California, Davis, Agriculture and Natural Resources, Cooperative Extension Specialist in Water \\ resources, USA \\ Correspondence: Saida Chaouch, University of Kasdi Merbah, Ouargla, Algeria. Tel: 213-666-008-885. E-mail: \\ saidachaouch@yahoo.fr
}

Received: May 22, 2021 Accepted: June 24, 2021 Online Published: July 5, 2021

doi:10.5539/sar.v10n3p52 URL: https://doi.org/10.5539/sar.v10n3p52

\begin{abstract}
The agricultural sector in the Saharan regions of Algeria has seen, since 1983, the development program of cereal cultivation irrigated by pivots thanks, essentially, to the availability of underground water resources which constitute its keystone. In Ouargla, these farms strongly supported by the public authorities and sustained by neo-farmers have marked progressions and regressions in space and in time, some have disappeared, others have undergone changes thus calling into question their durability. This research aims to assess the sustainability of these farms by the IDEA method (Sustainability Indicators of Farms Agricultural- Indicateurs de Durabilité des Exploitations Agricoles) based mainly on three scales; the agro-ecological scale, the socio-territorial scale and the economic scale. The analysis of 13 farms shows that this is an artificial production system, the installation of which is at great risk and depends heavily on the will of agricultural policies and entrepreneur-farmers. The economic scale seems to have the best score, however the profits generated by the farmers can be explained more by the consistent support of the State than by a tangible accounting balance. At the socio-territorial level, most of the components are failing, in particular a very low diversity of products and a strong lack of employment. The agroecological scale constitutes the limiting factor par excellence with an agriculture which consumes a lot of non-renewable water and energy and at the same time destroys the soil resource by the phenomenon of salinization. Thus the three scales are failing and the limiting factor par excellence is the environmental scale, the consideration of which is strongly recommended both nationally and internationally. This research also highlights the need for a revision of certain indicators of the IDEA method with a view to adapting it to the local context of arid zones and to the cereal agrosystem in Ouargla.
\end{abstract}

Keywords: agriculture, sustainability assessment, indicators, IDEA, cereals, arid zones, Algeria, Ouargla

\section{Introduction}

Cereals are of particular importance in Algeria, they occupy a strategic place in the national economy. As culinary habits, Algeria ranks first in the world for the consumption of cereals with an average of $205 \mathrm{~kg} /$ capita / year. Rastion and Bencharif 2007, report that $54 \%$ of energy and $62 \%$ daily protein intake came from these products. Best grain-producing areas in northern Algeria offer very modest yields about $15 \mathrm{qx} / \mathrm{ha}$. This is increasingly in difficulty compared to the demand. Thus Algeria has opted for the development of irrigated cereal cultivation in the Saharian regions relying on the availability of underground water resources. The framework of 83-18 APFA (Access to agricultural land ownership- Accession à la Propriété Foncière Agricole) Law and the Concession program allowed large agricultural areas to be carried out, equipped and allocated to neo-farmers who were supported by credits, tax exemptions and subsidies. Therefore, all socio-professional categories and from the four corners of Algeria have been strongly attracted. Côte, 1996 highlight that capitalist forms are struggling to fully emerge in northern Algeria, because all the structures are already settled. They flourish much more freely in Saharian regions in the form of ex nihilo creation, encouraged by both local context and public authorities.

However, experience has shown that cereal cultivation under pivots in Ouargla is faced of several constraints including high water consumption; soil salinization; technical problems that have strongly influenced yield levels. 
And the most important, is the human context, these neo-farmers, entrepreneurs recently versed in the agricultural sector, do not have a great connection with agriculture and do not hesitate to seek a better field of benefit. This policy is strongly contested by many authors; its fragility does not need any proof. The activity abandonment and / or its reorientation towards other more convenient agro systems is often the finality of these exploitations. In spite of this, it continues to attract new developers to new lands and who risk the same fate, thus paying no attention to the sustainability. Indeed, the sustainability of any project is subject to "the social relevance and equity of the solutions proposed, ecological prudence, economic efficiency, the cultural dimension and the territorial dimension" Ignacé, 1994. Landais, 1998 evokes four links "the economic link; the social connection; the bond between generations which is a particular dimension of the social bond; and the ecological or environmental link". For agriculture, Zahm et al, (2015) propose as a definition of sustainable farming, retaining that of Landais (1998) "a farm is qualified as sustainable if it is" viable, liveable, transmissible and reproducible ".

Researchers efforts in this field provide several methods to research and farming, including RAD, DIALECTE, ARBRE and IDEA. The opportunity to carry out a systemic and multidisciplinary analysis of agricultural systems are provided by the IDEA method, and it opens up concrete prospects for progressing towards more sustainable agriculture (Vilain et al., 2002).

According to Zahm, 2008, the geographical area of application of the IDEA is not limited; he specifies that the IDEA was developed primarily to analyze the sustainability of the major types of French agricultural systems. In the European Union, it has also already been used in Romania and Scotland. Adaptation work has taken place or is underway for Mediterranean (Lebanon, Tunisia, Algeria) or tropical (Benin, Mexico, Reunion) agriculture.

Briquel et al., 2001, state that assessment in the IDEA method is made for farmers, to serve as a diagnostic and monitoring tool or as a decision support tool. Zahm et al., 2013, affirm that IDEA method meets a dual objective. It Formalize the concept of sustainable farming in a theoretical framework for agronomical education needs; and operationalize this concept with a managerial objective. This method allows farmers willing to engage in a sustainable agriculture process to assess their level of overall performance in a self-assessment educational process.

Despite structure and functioning features of oasisian agriculture in arid zone, it is naturally subject to the same overall framework of sustainable agricultural development. Also, it is paired with inevitably different performance criteria depending on the agrarian areas and the rural societies (Chaouch, 2018). After suggestion of the IDEA method for assessing irrigated cereal farms sustainability in Ouargla, the purpose of this study is IDEA's conformity, adaptation and possibilities of readjustment in this region.

\section{Material and Methods}

\subsection{Studying Area}

Ouargla region also known as Oued M'ya valley is located at $800 \mathrm{~km}$ south-east of Algiers, over an area of $19,000 \mathrm{~km}^{2}$. It begins by Sedrata's ruins in the south, ancient Ibadites capital and ends at the entrance of Sebkha Safioune, $40 \mathrm{~km}$ further north. Rouvillois-Brigol, 1973 (Fig 01). It has six administrative districts known as municipalities and a population of more than 300,000 inhabitants (DPAT, 2019). It is a Saharan agro-ecological zone characterized by an arid climate and natural resources, especially underground water and promising land. It joins its very old oases, which are until today a source of life for the populations, a new development of the land wanted modern and sustainable. In Ouargla's region, there are 2485 ha of cereals under 105 pivots in total. Including 1176 ha (48 pivots) at the province of Sidi Khouiled, 890 ha (37 pivots) at N'goussa and 419 ha (20 pivots) in Remtha, municipality of Ouargla (DSA, 2018). 


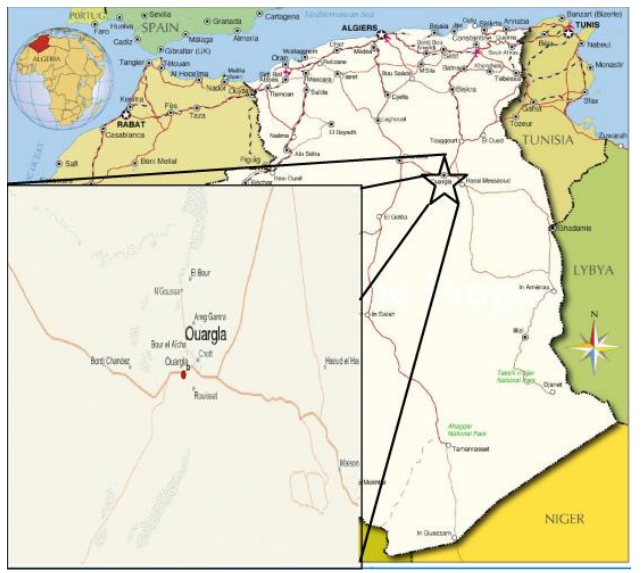

Figure 1. Situation of the Ouargla region (Oued Mya)

\subsection{Studying Method}

\subsubsection{Preliminary Diagnosis of Cereal Farms Based on Pivot Irrigation}

In order to understand the farms functioning, a socio-economic and technical diagnosis of cereal farms is extremely important from the study's beginning. This global basic approach is carried out according to the method of (Capillon \& Manichon, 1991).

\subsubsection{Sustainability Assessment by the IDEA Method of Cereal Farms Irrigated by Pivot}

The assessment of the sustainability of farms integrating the three axes of sustainability namely, social, economical and environmental; this could be supported within several methods framework. The comparison between the different evaluation methods, allowed us to choose the IDEA method in its third version (4th version in progress). This choice is based mainly on the fact that it is a systemic approach at the farm level by integrating the three dimensions of sustainability, specifically the agro-ecological, the socio-territorial and economical scales.

\subsubsection{Principles and Calculation Mode of the IDEA Method "Version 3"}

In 1998, the IDEA method was launched in France to enable a diagnosis of farm sustainability. It was published in 2000, reissued in 2003 in a second version. Zahm., 2008 explains that the 3rd version suggests improvements on indicators formulation and weighting adding that it has three scales, namely, Agro-ecological, Socio-territorial and Economic scales. Each sustainability scale is subdivided in components that synthesize characteristics of diagnosis sustainability. Each component groups together indicators, making a total of 42 sustainability indicators.

The calculation method is based on points system with a cap. All information is translated into sustainability basic units that determine the assigned score to each indicator. Sustainability points number attributed to each indicator is between zero limits and ceiling value. Each component is also limited, to a ceiling value which balances its relative weight and allows a very large number of technical combinations to achieve it. Sustainability scales are of the same weight and range from 0 to 100 points. The score of a farm for each of the three scales is the cumulative number of elementary units of obtained sustainability. Regarding the overall value of the three scales scores aggregation, the lowest sustainability is given to the final numerical value. Thus, applying the rule of limiting factors which is essential in ecosystems dynamics (Vilain, 2008).

\subsubsection{Sampling}

The choice of 13 surveyed farms is based mainly on their operation, those in stoppage, even temporarily, are eliminated from our sample. The multistage sampling technique is chosen which involves two sampling stages (i) dividing the population into clusters, here three provinces for better representativeness. (ii) Taking a sample from within each cluster by simple random sampling as practicable as possible. Indeed, the farm manager presence and the responses reliability constitute the lever for the survey form approval choice.

\subsubsection{Surveys and Data Analysis}

The surveys are based on survey sheet inspired by those proposed for the IDEA method in its third version. Excel software, http://www.idea.chlorofil.fr, is used of farm's data analysis for its preliminary diagnosis. The 
transmissibility indicator is pointed out as an exceptional case, which its evaluation is made on the basis of a fixed amount in (K Euro). This poses a problem for the local and current context, thus we adopted the proposed IDEA RUN study - Indicators method of agricultural sustainability (Lobietti et al., 2018) which makes it possible to approach the indicator through more convenient and flexible variables in space and time.

\section{Results and Discussions}

\subsection{Fundamental Features of Farmers and Farms}

\subsubsection{Farmers Age and their Educational Level}

The farmer's average age is 55 years old. The majority (62\%), are adults in the 40-65 age bracket, the youngest fewer than 40 represent a rate of $15 \%$ while farmers over 65 represent $23 \%$. The farmers educational level is quite acceptable.15\% of them have university diploma or specialized training, which is new in the agricultural sector so far dominated by the modest levels of training. $46 \%$ have a secondary level, $23 \%$ of primary and / or middle level and only $15 \%$ of farmers did not attend school.
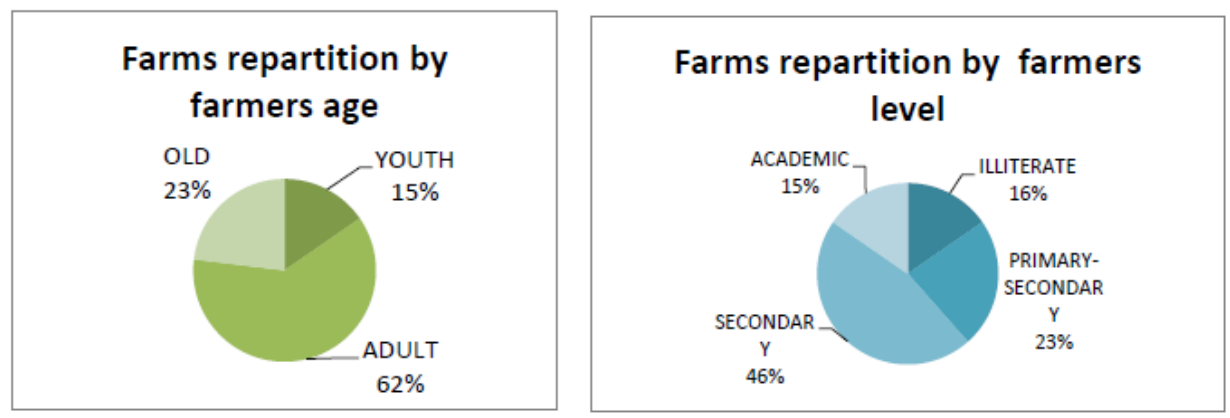

Figure 2. Distribution of farmers according to their age and educational level

\subsubsection{Filiation and Activity of Origin}

All the farmers have other activities in parallel, sometimes it is even the original one. Government incites to cereal growing using center pivot irrigation system by many measures, such as land allocation and bank loans. Thus, entrepreneurs, traders and public servants are encouraged. Farmers by descent, palm dates growers, exist in small numbers and have also benefited of new land to develop cereal cultivation under pivots.

\subsubsection{Farm Size and Cereal's Area}

It should be remembered that in Saharian arid zones, country of the oases, farms are usually small about 1 to 2 ha and even less for the traditional palm dates farming. However, with the arrival of new development, exceptionally large size perimeters of 30,60,100 ha and even more than 1000 ha were created. These perimeters are often considered of medium size for about 5 to 30 ha, large for 30 to 100 ha and very large for those over 100 ha. Thus, the total areas or farms sizes intended for pivot cereal farming vary between 30 and 1134 ha. In fact, $23 \%$ of surveyed farms are medium size. $46 \%$ are large farms and $31 \%$ are very large exceeding 100 ha.

The area under pivots irrigation system really cultivated of cereals ranges from 10 ha to 255 ha; it is respectively dominated by medium to large areas of $39 \%$ and $38 \%$. Farms with very large cereal areas represent $23 \%$. However, we note that even if very large farms exist, we have the clear dominance of medium to large cereal areas. Areas covered with pivots are not always sown.

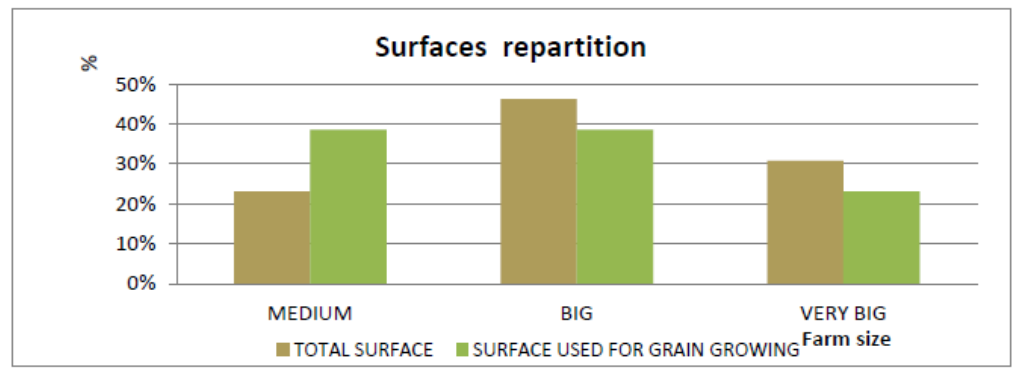

Figure 3. Distribution of total areas and cereals ones 


\subsubsection{Status and Land Origin}

$61 \%$ of farms are obtained from the APFA framework, law 83-18, and have therefore become private status as stipulated in this law. 39\% of allocated farms under concession, launched since 1997, are less than 20 years old. According to the concession texts, they remain in the governmental private domain.

\subsubsection{Labor Force}

Labors number is variable depending on pivots number. Farms with 1 single pivot need only one permanent worker, these represent more than half (62\%), 23\% have 2 to 4 workers and few of them have more than 4 workers representing less than $15 \%$. Permanent workers are recruited as responsible for the farm management and organization. Seasonal ones are also present during plowing-sowing periods and the harvest-threshing campaign. Concerning, family labor is totally absent.

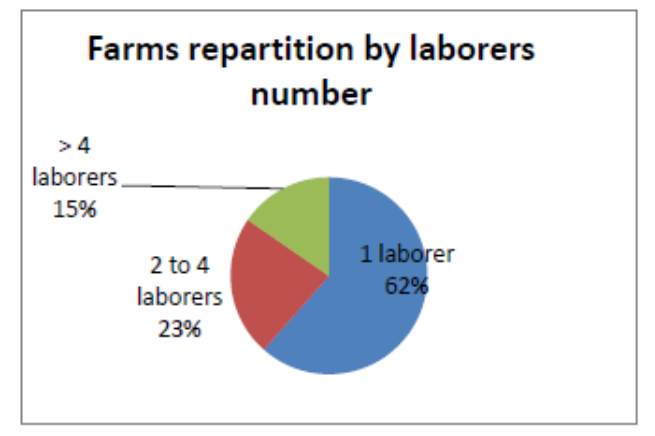

Figure 4. Distribution of farms according to labors number

\subsubsection{Irrigation}

Farms irrigation depends on two means : wells and Pivots. The majority of farmers dreel up to Miopliocene aquifer level, the average depth ranges from 100 to $400 \mathrm{~m}$, the flow rate is around $351 / \mathrm{s}$ and the salinity is 1.8 to $5 \mathrm{~g} / 1$ (BNEDER-BRLi, 1998). In numbers, $31 \%$ of farmers have only one borehole, $46 \%$ of cases have from 2 to 6 and $23 \%$ have 7 to 10 .

Pivots centers for irrigation are imported in their entirety, they cover areas ranging from 15 to 50 ha. Clear dominance is of those with 32 ha. Pivots number is variable from 1 to 10 . However, $38 \%$ of farms have only one pivot, 38\% have between $2-6$ and 23\% have more than 6 with a maximum of 10 .

\subsubsection{Agricultural Material}

Mechanization is fundamental for these farms and all farmers use agricultural equipment, however only $60 \%$ have their own equipment (tractor and towed equipment). $40 \%$ hire or use them free of charge to carry out operations and different tasks. For harvesting, Cereals and dried vegetables cooperative (CCLS) is responsible for this operation due to the excessively high cost of combine harvesters compared to the cereals area per farm.

\subsubsection{Bank Credit and State Support}

All farmers benefit from bank support made up of two types of credit; the "Rfig" for one year period, without interest but its amount is conditioned by certain reference point such as the land surface. The second one "Ettahhadi" for 05 years' period, without interest, however with late penalties, taxes and requiring guarantees thus causing hesitation among farmers. For state's support, it includes pivots with $50 \%$ to $60 \%$ of the reference price, hydraulic equipment from $40 \%$ to $50 \%$ of the reference price of boreholes and $20 \%$ compared to the reference prices of inputs.

\subsubsection{Yield and Profitability}

At these farms level, profitability is linked exclusively to cereal's yield. Therefore, our study highlights three classes of cereal yields (grain and straw) correlated with three classes of farm profitability.

- $23 \%$ of farms have low yields below 16 qx / ha, with a zero to negative gross margin. Main causes are; the non-respect of technical itineraries; the seeds quality; high cost of electric power imposing reductions in irrigation, combined with the lack of know-how; the deficit in agricultural extension and the little interest given by farmers having other more profitable occupations. 
- $62 \%$ of farms have tolerable to medium yields (from 16 to $40 \mathrm{qx} / \mathrm{ha}$ ), and a gross margin ranging from just the balanced one (10,000 DA / ha) to an encouraging one (134,000 DA / ha). These farms suffer from some above-mentioned problems but elude others.

- $15 \%$ of farms obtain good yields, higher than $40 \mathrm{qx} /$ ha and a gross margin more than 134,000 DA / Ha. This is due to interest that farmers bring to this activity, by the technical itinerary respect and efforts made to forge links with outreach workers.

\subsection{Analysis of Farm Sustainability Using the IDEA Method}

\subsubsection{Agro-ecological Sustainability Scale}

The agro-ecological sustainability scale brings together indicators illustrating the self-reliance capacity of farms in relation to the use of energy and non-renewable materials, which generate more or less pollution (Briquel et al., 2001). It allows to estimate the agricultural systems autonomy, according to the use of resources and energy. Also, it assesses their capacity to protect water and natural environments, or their contribution to various sources of pollution. All of these indicators highlight the system capacity to maintain, and even develop, long-term productive potential, through an assessment of the natural capital management mobilized by the production system (Lobietti et al., 2018).

Agro-ecological sustainability diagnosis is based on 18 indicators divided into three components namely, productions diversity, space organization and agricultural practices. For cereal farms irrigated by pivots in Ouargla, it presents low scores for the three components with a total of 20/100. The minimum recorded concerns the space organization with $2 / 33$. Domestic diversity also has a very low score of $3 / 33$. Farming practices has the best score about $15 / 34$.

The analysis of indicators by component shows that cereal- growing farms have low diversity score. And the farmers use the space under pivot in monoculture, dominated by durum wheat, soft wheat, barley and rarely oats. The genetic heritage enhancement and conservation is zero because the most widely used varieties Vitron, Siméto, Anza, Siété-cerros and Saida 186 come from the north of the country and / or imported. The surface organization indicates lower score as well. Large plots of 15 to 32, or even 50 ha, are cultivated annually without any rotation. Without livestock, neither use of space forage areas management nor organic matter. Even worse, the development of land, in certain places, trampled the routes formerly frequented by camels. Therefore, natural biodiversity is destructed, especially by the fact that there is no zone of ecological regulation in these environments.

Regarding the contribution to the territory environmental issues, the question is not currently addressed at all. For agricultural practices component, it seems that the score is better without being good. This is mainly linked to the low use of phytosanitary products. Phytosanitary problems are rare apart from the weed infestation. Farmers opt for cultural control (pre-irrigation) and herbicides use of is generally neglected. Soil resource protection is average due to the fact that sandy soils do not require heavy work, which is a great advantage. However, soil salinization by irrigation water is one of the serious consequences known for several years. According to an experience of two pilot farms in Gassi Touil, salt load multiplied by 4 to 6 times, after 5 years of irrigation (Daoud et al., 1994). Regarding fertilization, the skeletal nature of Saharian soils requires annual application of high chemical fertilizers doses, namely $4 \mathrm{qx}$ / ha of TSP and $8 \mathrm{qx} /$ ha of Urea $46 \%$ and sometimes trace elements. Despite, electric energy cost strongly contested by farmers. Water is used in an irrational way and considered insufficient, combined with the fuel which is essential for farms operating. Indeed, these two indicators show zero scores.

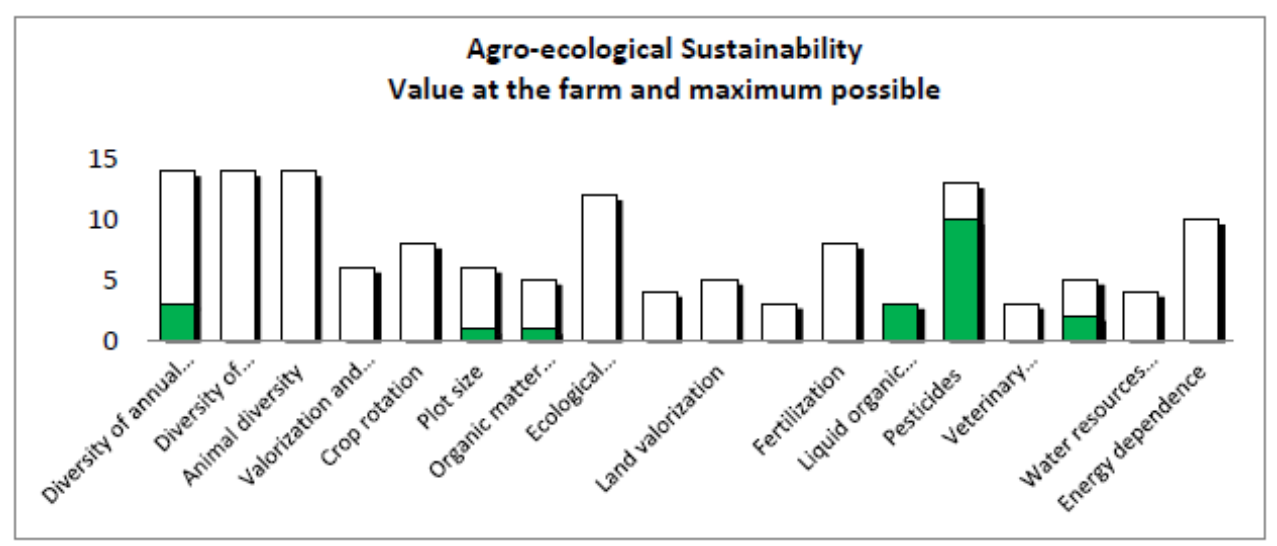

Figure 5. Agro-ecological sustainability scale 


\subsubsection{Socio-territorial Sustainability Scale}

According to Briquel et al., 2001, the socio-territorial sustainability scale is assessed using indicators that promote a set of objectives (human development, quality of life, ethics, local development, employment. Lobietti et al., 2018 add that this dimension responds to objectives centered on farm contribution to territory sustainability. It aims to assess the weight of farms services provided to both territory and community. It addresses issues of contribution to employment, local development, civic actions, etc. The indicators of this pillar combine easily quantifiable practices and behaviors with essentially qualitative elements. It is about farmers generally.

The socio-territorial sustainability diagnosis is also based on 18 indicators divided into three components; namely product and territory quality; employment and services; ethics and human development. For these cereal farms, this scale presents better scores but remains low for the majority. Total points are 35/100 points, the product and territory quality component is the lowest with a score of 4/33. In addition, Employment and Services component has a low score of only 8/33. For this scale, Ethics and Human Development component look good by $23 / 34$, something that is attributed more to the original activity of these farmers-entrepreneurs.

The government encourages strongly Cereal cultivation with pivot system irrigation and, even, manages it. CCLS constitutes the hinge of this sector; it ensures inputs endowment, threshing \& harvest and the product purchase. Under these circumstances farmers care very little about products quality. State provides large agricultural development of which agricultural tracks. As a result, cereal spaces accessibility is fairly good. However, there is no enhancement of built heritage and landscape in these remote and newly developed lands, nor of non-organic waste management, where their indicators value is zero.

Valuing by short channel, it is about industrial type chain. In the upper this sector marks a strong dependence on the external market for all inputs, and sale is ensured at farms head office by a single buyer (CCLS) at downstream. On another level, these farms do not present any autonomy and local resources development, nor concerned about animal products and by-products, producing no energy of agricultural or forestry origin and dont have seed autonomy. Rainfall couldnt be valued due to its Irregularity and rarety, it is only about 40mm / year.

Few farms could serve from time to time as educational farms. Otherwise, there is no services rendered to the territory niether agrotourism nor even integration practices or social experimentation. In addition, employment contribution is very low because the technical management of farms irrigated by pivots requires very little labor. Workers stability poses a problem because they leave as soon as they acquire knowledge for a better salary. Throughout the region, other forms related to work such as the job bank, mutual aid, employer's groups and networking do not exist.

Cereal farm needs specific agricultural equipment. However, its underuse in common is due to the surface area per farm. Regarding worldwide food balance contribution and planetary resources sustainablity management, these farms have theire entire UAA intended for protein plants production. This fact causes the indicator to be peaked at its maximum value while for the product nature, there is no opening for direct sale or tasting.

Farmer do not benefit from any training, and is very little involved in associative and / or elective structures. Nevertheless, academics often make visits and they are authorized and welcomed. Work intensity is low during one to three weeks between sowing and threshing harvest. Neo-farmers generally, coming from the entrepreneurship sector, enjoy a very acceptable quality of life. They dont have geographical, social or cultural isolation feeling . They have, also accommodation conditions for workforce. Facility security is medium to good, and storage rooms premises for phyto products are, for some, in compliance with regulatory recommendations. This state means that the sustainability of cereal farms irrigated by pivots is questioned and experience shows that without the very strong and incoditioned State's participation, these neo-farmers can easily abandon this option and move towards more profitable activities. 


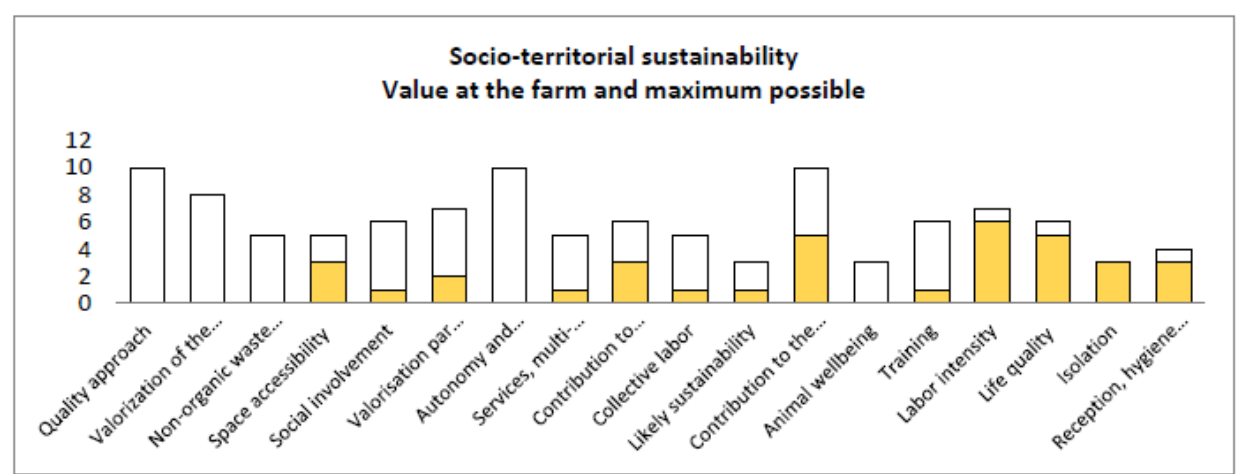

Figure 6. Socio-territorial sustainability scale

\subsubsection{Economical Sustainability Scale}

The economic sustainability scale addresses the practices and behaviors of farmers assessed in the previous scales, from an economic perspective. Under market conditions, the farm must generate a sufficient current income to ensure the farmer a certain autonomy in his choices and to allow him to move towards a sustainability approach (Briquel et al., 2001). Assessing economic sustainability goes beyond analyzing only short-term economic performance. Indeed, if production system sustainability depends on its economic viability, it also depends in medium and long terms on its transferability, efficiency and independence (Lobietti et al., 2018).

Economical sustainability diagnosis is based on 06 indicators divided into four components. They are namely Viability, Independence, Transferability and Efficiency. It has a total score of 36/100 points. The viability component gives the best score of 18/30, followed by efficiency component with 11/25 while components, independence and transmissibility, have respectively $3 / 25$ and $4 / 20$. The studied model presents agricultural businesses rather than simple farms; this means that income far exceeds the minimum wage. Therefore, there is a very efficient economic viability with fairly production process of acceptable efficiency. However, specialization rate remains zero and these farms are totally dependent. They have no financial autonomy, and are very sensitive to public grants without any certainty of their transmissibility.

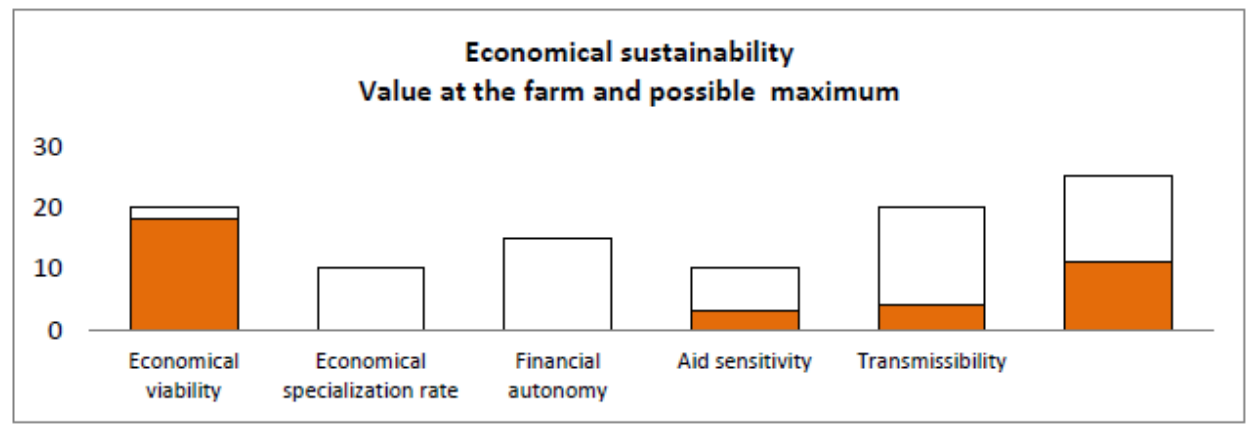

Figure 7. Economical sustainability scale

\subsection{Global Synthesis}

Overall analysis illustrated in Figure 08 and Table 01 below, gives a weakness of all sustainability scales of cereal farms irrigated by pivots in the Ouargla region. Agro-ecological is as a limiting factor; its scale has a score of 20 points. Both other scales do not have good scores; they are only 35 points for socio-territorial scale and a maximum of 36 points for the economical one.

Table 1. Summary of cereal farms sustainability in Ouargla

\begin{tabular}{lll}
\hline Sustainability & Farms Value & Maximum \\
\hline Agroecological & 20 & 100 \\
Socioterritorial & 35 & 100 \\
Economical & 36 & 100 \\
Durability rating & $\mathbf{2 0}$ & \\
\hline
\end{tabular}




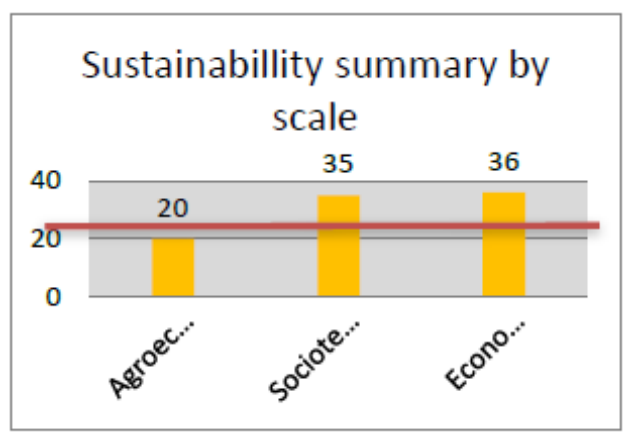

Figure 8. Sustainability scores Summary

Graphical Display of farms sustainability components confirms the analysis, majority of indicators have strong failure, namely diversity, space organization, quality of regional products, employment and services, independence and transferability. In the other hand, few scores are strength but with fair average values, such as viability, efficiency, agricultural practices, ethics and also human development.

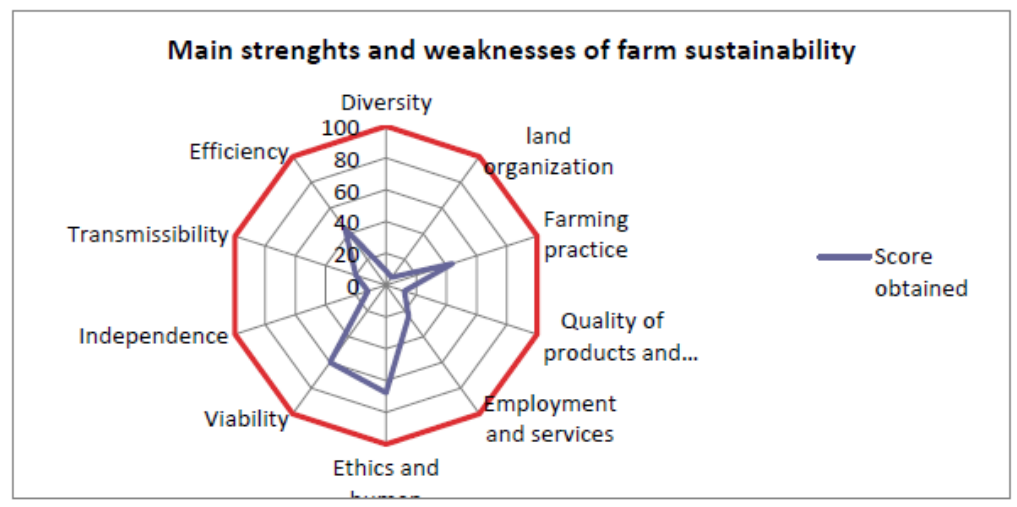

Figure 9. Main strengths and weaknesses of sustainability

\section{Conclusion}

In order to meet the ever-increasing demand for cereals products in Algeria, an agricultural dynamic created within development policy framework of irrigated cereals by pivot. This grain farming counts on natural resources mobilization, in particular the groundwater of Saharian regions, and Ouargla seems a priori. However, the current study shows that this option faces social, technico-economic and ecological constraints.

Low sustainability across its three scales starting with the agro-ecological scale, weak scores for the three components; poor crops diversity and a strong orientation towards mineral fertilization, water salinity and soil salinization, over exploration of non-renewable water resources and heavy energy use. Banking obstacles cause farmers' reluctance to obtain bank loans and hamper the functioning of farms.

It is also failing for socio-territorial scale characterized by low scores for the three components. The failure is due, fundamentally, to farmer's lach of organization lack and bad relation with their territory considered as being an exclusive production place. The clear extension system failure which greatly disrupts the establishment farmer relationship, and the fact that (CCLS) is conventionally the unique buyer; regardless of the product quality makes the quality approach very poor.

For the economic scale although we have a ceiling score for viability, this is due to the nature of the activity so supported by the government. The policy aims to increase cereals production in order to reduce the import bill. However, this cannot conceal the economic fragility caused by clearly failing indicators, in particular financial autonomy, the rate of specialization and above all the transferability, key, of sustainability. Indeed, even if the state continues to encourage this option, the pivotal cereal farming cereal cultivation under pivot is facing sufficient difficulties; following poor results judged to be in continual degradation make an abandonment and reorientation of farmers towards other production systems. Furthermore, operators become motivated to this real 
purpose. In fact, this work notes that most farms are moving towards multipurpose systems by introduction and development of palm dates growing, market gardening and for some fodder crops with or without livestock. Chaouch, 2016 confirms that it is a production system doomed to failure, specifying « We would like to point out that even if technical feasibility conditions do not pose any problems, this system cannot be economically profitable because it is the State which covers the possible deficit».

According to the IDEA method in its third version, we identify inadequacies; therefore we suggest reviews for a better method application to the local context;

Farmers do not always have accounting documents, which poses a calculation problem for us because too many approximations could lead to incorrect results. To this end, we offer alternatives, in particular those presented by Lobietti et al, 2018 "However, a large part of Reunion's farms do not have accounts. In order to not condition the evaluation of this pillar by the presence of an accounting, the economic indicators concerned include two calculation methods: one precise version, requiring recourse to the balance sheet, the other, simplified, using benchmarks established in the appendices of this guide ". This case is all the more true for the Transmissibility indicator where the fixed amount proposed as a scale couldn't take into account farms multiple situations which vary in space and time.

Benchmark lack of crops and animal species in the region poses a problem in measuring local heritage, and the related indicators cannot be properly assessed. This is not specific to the agro system studied nor to the region because this task, which is so important for biodiversity, is only at its beginning in Algeria.

The choice of indicators and their weightings can be revised in order to offer several variants depending on the agrosystem studied. On this subject, in Ouargla and concerning cereals under pivots, some indicators proposed are not suitable we will cite in particular the indicators "grassland", "livestock", "mode of work by employers group and working in a network", "Contribution to the environmental issues of the territory"

There are two types of zero score indicators; (i) zero-score indicators which explain a real problem with regard to sustainability, and those are to be maintained in order to judge the farms sustainability. (ii) Zero score indicators which could be explained by the agro system's nature and sometimes by the natural characteristics of the region. They pose a methodical problem not necessarily linked to sustainability because it is not a failure. Therefore, the indicator in question is considered unsuitable and can be eliminated or replaced by another more suitable for the agro system and the region we will cite in particular the indicators "meadows", "livestock", "mode of work by group of employers and networking", "contribution to the environmental issues of the territory".

We conclude that the IDEA method can be applied for the evaluation of the sustainability of cereal farms irrigated by pivot in the Ouargla region, subject to a review of the choice of some indicators, their weightings or even their substitution in order to propose several variants according to the agro system and the region of the study.

\section{Acknowledgments}

Our sincere thanks to the researchers who initiated and developed this method, which is so important for the reflections on the question of sustainability of farms. We will cite in particular Frédéric ZAHM, Lionel VILAIN Philipe VIAUX, Mohamed GAFSI and Bernard DEL'HOMME whose work is the basis of this research.

\section{References}

BNEDER-BRLi (1998). Plan Directeur Général du Développement des Régions Sahariennes. Synthèse des simulations hydrauliques. pp. 60.

Briquel, V., Vilain, L., Bourdais, J. L., Girardin, P., Mouchet, C., \& Viaux, P. (2001). La méthode IDEA (indicateurs de durabilité des exploitations agricoles): une démarche pédagogique. Ingénieries eau-agriculture territoires, Lavoisier, IRSTEA, CEMAGREF. pp. 29-39. Retrieved from https://hal.archives-ouvertes.fr/hal-00464508/document

Capillon, A., \& Manichon, H. (1991). Guide d'étude de l'exploitation agricole à l'usage des agronomes (2rd ed.). éme édition, INA, Paris Grignon et APCA. pp. 65.

Chaouch, S. (2016). Développement agricole durable à Ouargla. Nouvelles technologies et mutations socioéconomiques. EUE. Edition Universitaires Européenne. pp. 369.

Chaouch, S. (2019). Développement agricole durable dans les zones arides: vers quels espaces? Et quelles sociétés ? (cas de la wilaya de Ouargla - algérie). Revue des BioRessources, 9(2). 88-104. Retrieved from https://journals.univ-ouargla.dz/index.php/RBR/article/view/1441 
Côte, M. (1996). Pays, paysages, paysans d'Algérie: CNRS. Paris. pp. 282.

Daoud, Y., \& Halitim, A. (1994). Irrigation et salinisation au Sahara algérien. Sécheresse, 5(3), 151-160. Retrieved from https://www.jle.com/fr/revues/sec/e-docs/irrigation_et_salinisation_au_sahara_algerien_270 877/article.phtml

DPAT. (2019). Annuaire statistique de la wilaya de Ouargla. (Fichier numérique).

DSA. (2019). La situation de la céréaliculture sous pivots dans la wilaya de Ouargla. (Fichier numérique).

Ignacy, S. (1994). Le développement reconsidéré: quelques réflexions inspirées par le Sommet de la Terre. Tiers-Monde, 35(137), 53-60. https://doi.org/10.3406/tiers.1994.4848

Landais, E. (1998). Problématique et débats Agriculture Durable: les fondements d'un nouveau contrat social. Courrier de l'environnement, INRA, n.33. Retrieved from https://hal.archives-ouvertes.fr/hal-01204654/file/C33Landais.pdf

Lobietti, M., Michels, T., Poletti, S., Cabot, V., Danflous, J-P., Le, B. F., ... Zahm, F. (2018). La méthode IDEA Réunion - IDEA RUN - Indicateurs de durabilité des exploitations agricoles. s.l. CIRAD-DAAF. pp. 154.

Rastion, J. L., \& Bencharif, A. (2007). Concepts et méthodes de l'analyse des filières agroalimentaire: application par la chaine globale de valeur au cas des blés en Algérie. Working paper n 07, UMR MOISA, Montpellier. Retrieved from http://www1.montpellier.inra.fr/bartoli/moisa/bartoli/download/moisa2007_pdf/WP_7-2007.pdf

Rouvillois-Brigol, M. (1973). Variations et organisation d'un espace rural au milieu désertique: Le pays de Ouargla (Sahara Algérien). Thèse de doctorat en Géographie, Université Sorbonne. Paris (France). pp. 273.

Vilain, L. (2008). La méthode IDEA - Indicateurs de durabilité des exploitations agricoles - Guide d'utilisation (3rd ed.). Educagri.

Vilain, L., Girardin, P., Viaux, P., \& Mouchet, C. (2002). IDEA une méthode d'évaluation de durabilité des systèmes agricoles. Travaux et innovations, 91, 18-22.

Zahm, F. (2008). IDEA version 3 (www.idea.portea.fr) Indicateurs de Durabilité des Exploitations Agricoles. Fiche outils. Retrieved from http://www.erytage.fr/webplage/images/stories/pdf/ficheidea.pdf

Zahm, F., Alonso, U. A., Boureau, H., Del'homme, B., Barbier, J. M., ... Redlingshofer, B. (2015). Agriculture et exploitation agricole durables : état de l'art et proposition de définitions revisitées à l'aune des valeurs, des propriétés et des frontières de la durabilité en agriculture. Innovations Agronomiques, INRA, 2015, 105-125. Retrieved from https://www6.inrae.fr/ciag/content/download/5717/43271/file/Vol46-9-Zahm.pdf

Zahm, F., Ugaglia, A. A., \& Del'Homme, B. (2013). L'evaluation de la performance globale d'une exploitation agricole. Synthèse des cadres conceptuels, des outils de mesure et application avec la méthode IDEA. 8eme Congrès du RIODD, Lille, France. pp. 32. Retrieved from https://hal.archives-ouvertes.fr/hal-00862865/document

\section{Copyrights}

Copyright for this article is retained by the author(s), with first publication rights granted to the journal.

This is an open-access article distributed under the terms and conditions of the Creative Commons Attribution license (http://creativecommons.org/licenses/by/3.0/). 